"Impact of factors on the utilization of agricultural credit of banks: an analysis from the borrowers' perspective"

\begin{tabular}{|c|c|}
\hline AUTHORS & $\begin{array}{l}\text { Lokesha } \\
\text { lqbal Thonse Hawaldar (D https://orcid.org/0000-0001-7181-2493 } \\
\text { [R https://publons.com/researcher/1456475/iqbal-thonse-hawaldar/ }\end{array}$ \\
\hline ARTICLE INFO & $\begin{array}{l}\text { Lokesha and Iqbal Thonse Hawaldar (2019). Impact of factors on the utilization of } \\
\text { agricultural credit of banks: an analysis from the borrowers' perspective. Banks } \\
\text { and Bank Systems, 14(1),181-192. doi:10.21511/bbs.14(1).2019.16 }\end{array}$ \\
\hline DOI & http://dx.doi.org/10.21511/bbs.14(1).2019.16 \\
\hline RELEASED ON & Monday, 01 April 2019 \\
\hline RECEIVED ON & Monday, 19 November 2018 \\
\hline ACCEPTED ON & Wednesday, 13 March 2019 \\
\hline LICENSE & $\begin{array}{l}(\mathrm{cc}) \overline{\mathrm{EY}} \\
\text { This work is licensed under a Creative Commons Attribution } 4.0 \text { International } \\
\text { License }\end{array}$ \\
\hline JOURNAL & "Banks and Bank Systems" \\
\hline ISSN PRINT & $1816-7403$ \\
\hline ISSN ONLINE & $1991-7074$ \\
\hline PUBLISHER & LLC "Consulting Publishing Company "Business Perspectives" \\
\hline FOUNDER & LLC "Consulting Publishing Company "Business Perspectives" \\
\hline
\end{tabular}

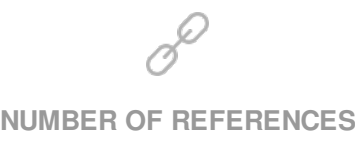

16

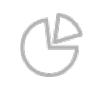

NUMBER OF FIGURES

0

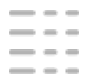

NUMBER OF TABLES

17

(C) The author(s) 2022. This publication is an open access article. 


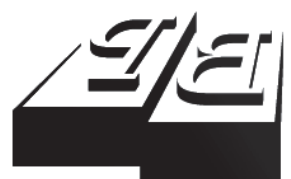

BUSINESS PERSPECTIVES

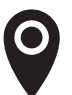

LLC "CPC "Business Perspectives" Hryhorii Skovoroda lane, 10, Sumy, 40022, Ukraine

www.businessperspectives.org

Received on: $1^{\text {th }}$ of November, 2018 Accepted on: $13^{\text {th }}$ of March, 2019

(C) Lokesha, Iqbal Thonse Hawaldar, 2019

Lokesha, Assistant Professor, Department of Commerce, Government First Grade College, Punjalakatte, Belthangady, Karnataka, India.

Iqbal Thonse Hawaldar, Professor, Department of Accounting and Finance, College of Business Administration, Kingdom University, Bahrain.

\section{(c) (1)}

This is an Open Access article, distributed under the terms of the Creative Commons Attribution 4.0 International license, which permits unrestricted re-use, distribution, and reproduction in any medium, provided the original work is properly cited.
IMPACT OF FACTORS

ON THE UTILIZATION

OF AGRICULTURAL CREDIT

OF BANKS: AN ANALYSIS FROM

THE BORROWERS' PERSPECTIVE

\begin{abstract}
Agricultural credit is required for the development of agriculture scenario in any economy. Commercial, cooperative and regional rural banks have extended agricultural credit to the farmers in Dakshina Kannada district of India. The effectiveness of agricultural credit system depends on the utilization of credit funds by the borrowers. The present study made an attempt to understand the factors influencing the utilization of agricultural credit of banks in Dakshina Kannada. The study used primary and secondary data. Primary data are gathered from the borrowers of banks operating in Dakshina Kannada district. The study found that there is an impact of demographic, agriculture and agricultural credit factors on the purpose of utilization of agricultural credit in Dakshina Kannada district.
\end{abstract}

\section{Keywords agricultural credit, banks, utilization of credit}

\section{JEL Classification Q14, G21}

\section{INTRODUCTION}

The adequate and timely availability of credit at reasonable rates is crucial for agricultural development. The public sector banks have made commendable progress in terms of wide banking network, particularly after nationalization of banks. The number of offices of public sector banks increased rapidly from 8,262 in June 1969 to 68,355 by March 2005. One of the major achievements in the post-independent India has been widening the spread of institutional machinery for agricultural credit and decline in the role of non-institutional sources (Seena, 2015). Gulathi and Bathla (2002) stated that, to combat the problem of defaults as well as to ensure financial viability of the rural banking system, RBI and NABARD have taken several policy and institutional measures. Introduction of Kisan Credit Cards is an effective step towards speedy loan delivery and avoidance of defaults. In 2010-2011, the government of India advised all banks to provide appropriate banking facilities to habitations having a population in excess of 2000 by March, 2012, using various models and technologies including branchless banking and Business Correspondents (BCs). In 2014-2015, banks lent Rs. 845,328 crores of agricultural credit in India. In 2015-2016, banks have disbursed Rs. 877,527 crores of agricultural credit. Banks are required to find innovative ways of reaching out to farmers, especially small and medium ones, to improve the performance of agriculture for inclusive growth and poverty reduction. There is a need to improve the performance of agricultural sector by improving the flow of agricultural credit. This requires effort from 
commercial banks, regional rural banks and cooperatives. The direct agricultural credit amount has a positive and statistically significant impact on agricultural output and its effect is immediate (Das et al., 2009). But if the credit is not utilized for the right purpose, there are chances of non-repayment of credit. This would result in failure of entire agricultural credit system. The utilization of this agricultural credit fund determines the effectiveness of repayment. In this regard, an attempt is made to analyze the factors influencing the purpose of utilization agricultural credit by borrowers in Dakshina Kannada district of Karnataka. This would help bankers to understand the extent of credit utilized by the farmers on productive activities.

\section{LITERATURE REVIEW}

In order to understand the different views on agricultural credit, few literatures on agriculture related aspects are analyzed. There are studies focused on the impact of agricultural credit utilization. It is proved that formal credit has played a critical role in increasing the net farm incomes and per capita monthly household expenditures of Indian farm families and there were initiatives taken by the Government and RBI to improve the accessibility of institutional credit to farmers (Kumar et al., 2010; Lokesha et al., 2017). There is an impact of institutional credit on positive relationship with land size (Kumar et al., 2017). It is also seen that the weaker sections of the society and small land holders are still going to non-institutional sources for their requirements which charges more interest (Kumar et al., 2007). The quantum of agricultural credit by banks provided by farmers has been influenced by a number of socio-demographic factors. There is also a positive impact of education in the family of farmers which affects the increased quantum of credit by farmers (Seena, 2015). The utilization of agricultural credit for productive purposes like agriculture, animal husbandry, cottage industry and business investment as well as consumptive purposes like domestic, social, educational and health (Ali et al., 2011). The utilization pattern and the repayment of agricultural credit are related. In case of defaulters, 69.23 percent of borrowers have utilized the credit for the stipulated purpose. Among the regular payers, only 9.20 percent of borrowers have misutilized the credit; while in case of defaulters, 30.77 percent of borrowers have misutilized the credit (Chahal, 2011). It was also found that better performance by farmers was because of prudent investment they made in the financial and physical assets and better utilization of factors and inputs (Selvaraj \& Palajikumar, 2015). The repayment of loan by borrowers is crucial for the success of agricultural credit system and in this connection, utilization of credit funds influences their repayment. The delay in getting loans is identified as the main reason for misutilization of the loan amounts. Majority of the respondents had proper utilization of the loan amount (Alexpandi \& Rameshkumar, 2015). There is a positive relation between the productive utilization of credit and size of the land holding and per capita income of farmers. But there is also a negative relationship between the productive use of credit and the area of crops grown by the borrowers (Dasgupta \& Dey, 2015). The repayment of credit depends on the utilization pattern of the agricultural credit by farmers. The amount of credit in majority of the respondents is of less amount. Majority of the respondents (91.5\%) have a repayment obligation of less than Rs. 10,000, and the repayment of credit is made from several income generated activities (Kumar Santhosh, 2013). It is also found that small percentage, namely 24.94 percent of short-term loans, 15.12 per cent of medium-term loans and 17.95 percent of long-term credit, were misutilized by the respondents (Sapkal et al., 2010). This shows that there is very less percentage of misutilization of credit funds by the borrowers. Many studies note that willful default is the reason of default in agricultural credit (Selvaraj \& Palajikumar, 2015; Lokesha, 2016).

\section{OBJECTIVE}

The objective of the paper is to understand the impact of factors on the purpose of utilization of agricultural credit funds from borrowers' perspective.

\section{METHODOLOGY}

The data required for the study are collected from primary and secondary sources. Primary data are collected from the borrowers of agricultural credit 
from the banks operating in Dakshina Kannada district. The respondents are selected from different types of banks consisting of public, private, cooperative and regional rural banks. Totally, 1,167 borrowers from 80 banks are selected for the study. The number of sample respondents is selected based on the percentage of total borrowers of agricultural credit from three public sector banks, one private sector, one cooperative and one regional rural bank. The selection of banks is based on the agricultural credit granted by them. The data on banks and borrowers were collected at Lead bank office for DK district situated in Mangalore. The multi-stage disproportionate stratified sampling method was used to select respondents. 1,282 questionnaires were distributed. However, there were few questions not answered by the respondents. Such unfilled questionnaires were not considered in the study. The response rate was 91 percentages. To test the validity of the questionnaire, Cronbach alpha was used and it was 0.76 for borrower's questionnaire and 0.834 for lender's questionnaire.

\section{ANALYSIS AND DISCUSSION}

The data collected from questionnaire are analyzed using SPSS and are presented below (Table 1).

Table 1. The purpose of the agricultural credit utilization

\begin{tabular}{l|c:c} 
& & Source: Primary data. \\
\hline \multicolumn{1}{c}{ Purpose } & Frequency & Percentage \\
\hline Agriculture & 934 & 80 \\
\hline Non-agriculture & 233 & 20 \\
\hdashline Total & 1,167 & 100 \\
\hline
\end{tabular}

In terms of utilization of agricultural credit funds, it is found that 80 percent of respondents have tak- en agricultural credit with the purpose of using it for agriculture and 20 percent have taken agricultural credit with the purpose of utilization for non-agricultural activities like business, marriage and house construction. This indicates that majority of farmers use agricultural credit funds for the right purpose. The result is also consistent with Mishra and Subhay (2003) and Sapkal et al. (2010). Further it is analyzed in detail by understanding the impact of demographic, agriculture and credit related factors on the purpose of utilization of agricultural credit funds. The researchers have formulated and tested three hypotheses.

\subsection{Hypothesis 1}

H1.1: There is a significant impact of respondents' demographic factors on the purpose of utilization of agricultural credit funds.

\section{H1.0: There is no significant impact of respondents' demographic factors on the purpose of utili- zation of agricultural credit funds.}

It is found from the analysis (see Table 2) that $\mathbf{1 8 . 2}$ percent of the male respondents used agricultural credit funds for non-agricultural activities and 30.4 percent of the female respondents used them for non-agricultural activities. Further, Chisquare test showed that male and female ratio has a significant impact on the purpose of agricultural credit utilization, as Chi-square test value is $\mathbf{1 3 . 6 7 6}$ and $p=0.000<0.01$. The number of male respondents who used agricultural credit funds for agriculture is significantly higher compared to female respondents. This is because female respondents had more commitments from family and had to meet their expenses. Thus, they utilized agricultural credit for non-agricultural activities more than the male respondents.

Table 2. Impact of gender on the purpose of agricultural credit utilization

Source: Primary data.

\begin{tabular}{|c|c|c|c|c|c|}
\hline \multirow{2}{*}{ Gender } & \multicolumn{2}{|c|}{ Purpose of utilization } & \multirow{2}{*}{ Total } & \multirow{2}{*}{$\begin{array}{c}\text { Chi-square } \\
\text { test }\end{array}$} & \multirow{2}{*}{$p$-value } \\
\hline & Agriculture & Non-agriculture & & & \\
\hline \multirow{2}{*}{ Male } & 815 & 181 & 996 & \multirow{6}{*}{13.676} & \multirow{6}{*}{$\begin{array}{c}0.00 \\
\mathrm{HS}\end{array}$} \\
\hline & $81.80 \%$ & $18.20 \%$ & $100.00 \%$ & & \\
\hline \multirow{2}{*}{ Female } & 119 & 52 & 171 & & \\
\hline & $69.60 \%$ & $30.40 \%$ & $100.00 \%$ & & \\
\hline \multirow{2}{*}{ Total } & 934 & 233 & 1167 & & \\
\hline & $80 \%$ & $20 \%$ & $100 \%$ & & \\
\hline
\end{tabular}


Table 3. Impact of age on the purpose of agricultural credit utilization

\begin{tabular}{|c|c|c|c|c|c|}
\hline \multirow{2}{*}{ Age } & \multicolumn{2}{|c|}{ Purpose of utilization } & \multirow{2}{*}{ Total } & \multirow{2}{*}{ Chi-square test } & \multirow{2}{*}{$p$-value } \\
\hline & Agriculture & Non-agriculture & & & \\
\hline \multirow{2}{*}{$<25$} & 44 & 7 & 51 & \multirow{16}{*}{41.153} & \multirow{16}{*}{$\begin{array}{c}0.00 \\
\mathrm{HS}\end{array}$} \\
\hline & $86.30 \%$ & $13.70 \%$ & $100.00 \%$ & & \\
\hline \multirow{2}{*}{$25-30$} & 27 & 2 & 29 & & \\
\hline & $93.10 \%$ & $6.90 \%$ & $100.00 \%$ & & \\
\hline \multirow{2}{*}{$31-35$} & 39 & 8 & 47 & & \\
\hline & $83.00 \%$ & $17.00 \%$ & $100.00 \%$ & & \\
\hline \multirow{2}{*}{$36-40$} & 74 & 39 & 113 & & \\
\hline & $65.50 \%$ & $34.50 \%$ & $100.00 \%$ & & \\
\hline \multirow{2}{*}{$41-45$} & 123 & 54 & 177 & & \\
\hline & $69.50 \%$ & $30.50 \%$ & $100.00 \%$ & & \\
\hline \multirow{2}{*}{$46-50$} & 341 & 55 & 396 & & \\
\hline & $86.10 \%$ & $13.90 \%$ & $100.00 \%$ & & \\
\hline \multirow{2}{*}{$>50$} & 286 & 68 & 354 & & \\
\hline & $80.80 \%$ & $19.20 \%$ & $100.00 \%$ & & \\
\hline \multirow{2}{*}{ Total } & 934 & 233 & 1167 & & \\
\hline & $80 \%$ & $20 \%$ & $100 \%$ & & \\
\hline
\end{tabular}

Table 3 shows that 34.5 percent of respondents of the age group of 36-40 years, 30.5 percent (41-45 years), 19.2 percent (above 50 years), 17.0 percent of respondents of age group of 31-35 years, 13.9 percent (46-50 years) and 6.9 percent of respondents of the age group of 25-30 years have utilized agricultural credit for non-agricultural activities. There is a highly significant impact of the age group of respondents on the purpose of agricultural credit utilization, as Chi-square test value is 41.153 and $p=0.000<0.01$. It can be observed that the majority of the respondents below 35 years and above 46 years have utilized agricultural credit for agricultural activities compared to other age groups.

It is revealed that 47.1 percent of the respondents without schooling, 45.2 percent of the respondents with post graduate education and 27.8 percent of respondents with diploma education have utilized agricultural credit for non-agricultural activities. There is a highly significant impact of the educa-

Table 4. Impact of educational level on the purpose of agricultural credit utilization

\begin{tabular}{|c|c|c|c|c|c|}
\hline \multirow{3}{*}{ Education } & & & \multicolumn{3}{|c|}{ Source: Primary data } \\
\hline & \multicolumn{2}{|c|}{ Purpose of utilization } & \multirow{2}{*}{ Total } & \multirow{2}{*}{ Chi-square test } & \multirow{2}{*}{$p$-value } \\
\hline & Agriculture & Non-agriculture & & & \\
\hline \multirow{2}{*}{ No schooling } & 45 & 40 & 85 & \multirow{16}{*}{61.657} & \multirow{16}{*}{$\begin{array}{c}0.00 \\
\mathrm{HS}\end{array}$} \\
\hline & $52.90 \%$ & $47.10 \%$ & $100.00 \%$ & & \\
\hline \multirow{2}{*}{ SSLC } & 479 & 109 & 588 & & \\
\hline & $81.50 \%$ & $18.50 \%$ & $100.00 \%$ & & \\
\hline \multirow{2}{*}{$P \cup C$} & 219 & 37 & 256 & & \\
\hline & $85.50 \%$ & $14.50 \%$ & $100 \%$ & & \\
\hline \multirow{2}{*}{ Graduate } & 155 & 28 & 183 & & \\
\hline & $84.70 \%$ & $15.30 \%$ & $100.00 \%$ & & \\
\hline \multirow{2}{*}{ Post-graduate } & 17 & 14 & 31 & & \\
\hline & $54.80 \%$ & $45.20 \%$ & $100.00 \%$ & & \\
\hline \multirow{2}{*}{ Diploma } & 13 & 5 & 18 & & \\
\hline & $72.20 \%$ & $27.80 \%$ & $100 \%$ & & \\
\hline \multirow{2}{*}{ Any other } & 6 & 0 & 6 & & \\
\hline & $100.00 \%$ & $0.00 \%$ & $100.00 \%$ & & \\
\hline \multirow{2}{*}{ Total } & 934 & 233 & 1167 & & \\
\hline & $80 \%$ & $20 \%$ & $100 \%$ & & \\
\hline
\end{tabular}


Table 5. Impact of marital status on the purpose of agricultural credit utilization

Source: Primary data.

\begin{tabular}{|c|c|c|c|c|c|}
\hline \multirow{2}{*}{ Marital status } & \multicolumn{2}{|c|}{ Purpose of utilization } & \multirow{2}{*}{ Total } & \multirow{2}{*}{ Chi-square test } & \multirow{2}{*}{$p$-value } \\
\hline & Agriculture & Non-agriculture & & & \\
\hline \multirow{2}{*}{ Married } & 848 & 212 & 1060 & \multirow{10}{*}{3.742} & \multirow{10}{*}{$\begin{array}{c}0.154 \\
\text { NS }\end{array}$} \\
\hline & $80.00 \%$ & $20.00 \%$ & $100.00 \%$ & & \\
\hline \multirow{2}{*}{ Unmarried } & 49 & 7 & 56 & & \\
\hline & $87.50 \%$ & $12.50 \%$ & $100.00 \%$ & & \\
\hline \multirow{2}{*}{ Divorced } & 5 & 3 & 8 & & \\
\hline & $72.50 \%$ & $27.50 \%$ & $100.00 \%$ & & \\
\hline \multirow{2}{*}{ Widower } & 32 & 11 & 43 & & \\
\hline & $72.50 \%$ & $27.50 \%$ & $100.00 \%$ & & \\
\hline \multirow{2}{*}{ Total } & 934 & 233 & 1167 & & \\
\hline & $80 \%$ & $20 \%$ & $100 \%$ & & \\
\hline
\end{tabular}

tional level of respondents on the purpose of agricultural credit utilization, as Chi-square test value is 61.657, $p=0.000<0.01$. Majority of the PUC, graduate and SSLC qualified respondents have utilized agricultural credit for agriculture activities. The respondents without schooling have utilized agricultural credit for non-agriculture significantly higher than educated respondents (see Table 4).

It is clear from Table 5 that 27.5 percent of divorced/widow respondents, 20 percent of married respondents and 12.5 percent of unmarried respondents have utilized agricultural credit for non-agricultural activities. Further Chi-square test shows that there is no significant impact of the marital status of respondents on the purpose of agricultural credit utilization, as Chi-square test value is $3.742, p=0.154>0.01$. This is because almost same percentage of respondents of different marital status have utilized agricultural credit for agricultural activities.

Table 6 shows that 26.8 percent of respondents with the income of less than Rs. 50,000, 23.3 percent of respondents with the income of Rs. 50,001 to Rs. $100,000,18.8$ percent with the income of Rs. 100,001 to Rs. $200,000,10.5$ percent with the income of Rs. 200,001 to Rs. 300,000 and 1 percent of respondents with the income of above Rs. 300,000 have utilized agricultural credit for non-agricultural activities. Further Chi-square tests show that there is a highly significant impact of the income level of respondents on the purpose of agricultural credit utilization, as Chi-square test value is 39.329 and $p$ $=0.000<0.01$. This is because the respondents with annual income of above Rs. 300,000 have utilized agricultural credit for agricultural activities more than those with any other income level.

Table 6. Impact of annual income on the purpose of agricultural credit utilization

Source: Primary data.

\begin{tabular}{|c|c|c|c|c|c|}
\hline \multirow{2}{*}{ Annual income } & \multicolumn{2}{|c|}{ Purpose of utilization } & \multirow{2}{*}{ Total } & \multirow{2}{*}{$\begin{array}{c}\text { Chi-square } \\
\text { test }\end{array}$} & \multirow{2}{*}{$p$-value } \\
\hline & Agriculture & Non-agriculture & & & \\
\hline \multirow{2}{*}{$<50,000$} & 183 & 67 & 250 & \multirow{12}{*}{39.329} & \multirow{12}{*}{$\begin{array}{c}0.00 \\
\mathrm{HS}\end{array}$} \\
\hline & $73.20 \%$ & $26.80 \%$ & $100.00 \%$ & & \\
\hline \multirow{2}{*}{$50,001-100,000$} & 356 & 108 & 464 & & \\
\hline & $76.70 \%$ & $23.30 \%$ & $100.00 \%$ & & \\
\hline \multirow{2}{*}{$100,001-200,000$} & 195 & 45 & 240 & & \\
\hline & $81.30 \%$ & $18.80 \%$ & $100.00 \%$ & & \\
\hline \multirow{2}{*}{$200,001-300,000$} & 102 & 12 & 114 & & \\
\hline & $89.50 \%$ & $10.50 \%$ & $100.00 \%$ & & \\
\hline \multirow{2}{*}{$>300,000$} & 98 & 1 & 99 & & \\
\hline & $99.00 \%$ & $1.00 \%$ & $100.00 \%$ & & \\
\hline \multirow{2}{*}{ Total } & 934 & 233 & 1167 & & \\
\hline & $80 \%$ & $20 \%$ & $100 \%$ & & \\
\hline
\end{tabular}


Table 7. Impact of educational level of children on the purpose of agricultural credit utilization

\begin{tabular}{|c|c|c|c|c|c|}
\hline \multirow{2}{*}{$\begin{array}{l}\text { Educational level } \\
\text { of children }\end{array}$} & \multicolumn{2}{|c|}{ Purpose of utilization } & \multirow{2}{*}{ Total } & \multirow{2}{*}{ Chi-square test } & \multirow{2}{*}{$p$-value } \\
\hline & Agriculture & Non-agriculture & & & \\
\hline \multirow{2}{*}{ No schooling } & 0 & 2 & 2 & \multirow{14}{*}{18.412} & \multirow{14}{*}{$\underset{\mathrm{HS}}{0.002}$} \\
\hline & $0 \%$ & $100.00 \%$ & $100.00 \%$ & & \\
\hline \multirow{2}{*}{ SSLC } & 167 & 46 & 213 & & \\
\hline & $78.40 \%$ & $21.60 \%$ & $100.00 \%$ & & \\
\hline \multirow{2}{*}{ PUC } & 125 & 43 & 168 & & \\
\hline & $74.40 \%$ & $25.60 \%$ & $100.00 \%$ & & \\
\hline \multirow{2}{*}{ Graduate } & 174 & 45 & 219 & & \\
\hline & $79.50 \%$ & $20.50 \%$ & $100.00 \%$ & & \\
\hline \multirow{2}{*}{ Post-graduate } & 245 & 65 & 310 & & \\
\hline & $79.00 \%$ & $21.00 \%$ & $100.00 \%$ & & \\
\hline \multirow{2}{*}{ Any other } & 174 & 25 & 199 & & \\
\hline & $87.40 \%$ & $12.60 \%$ & $100.00 \%$ & & \\
\hline \multirow{2}{*}{ Total } & 885 & 226 & 1111 & & \\
\hline & $79.70 \%$ & $20.30 \%$ & $100.00 \%$ & & \\
\hline
\end{tabular}

It is found from Table 7 that 100 percent of respondents with no educational level of children, 25.6 percent of respondents with PUC educational level of children, 21.6 percent of respondents with SSLC educational level of children, 21 percent of respondents with post-graduate educational level of children and 20.5 percent of respondents with graduate educational level of children have utilized agricultural credit for non-agricultural activities. Further Chi-square tests show that there is a significant impact of educational level of respondents' children on the purpose of agricultural credit utilization, as Chi-square test value is 18.412, $p=0.002<0.05$. The respondents having children without schooling have utilized agricultural credit for non-agricultural activities. The majority of respondents having children with education have utilized agricultural credit for agricultural activities.
It is clear from Table 8 that 25.2 percent of the respondents with more than two dependents, 19 percent of the respondents with 2-5 dependents and 15.7 percent of the respondents with less than two dependents have utilized agricultural credit for non-agricultural activities. Further Chisquare tests show that there is no significant impact of the number of dependents in the respondents family on the purpose of agricultural credit utilization, as Chi-square test value is 5.371 and $p$ $=0.068>0.05$.

It is seen from Table 9 that 45.3 percent of the respondents with extended family, 20.9 percent of the respondents with joint family and 13.5 percent of the respondents with nuclear family have utilized agricultural credit for non-agricultural activities. Further Chi-square tests show that

Table 8. Purpose of utilization of agricultural credit

Source: Primary data.

\begin{tabular}{|c|c|c|c|c|c|}
\hline \multirow{2}{*}{$\begin{array}{c}\text { Number } \\
\text { of dependents }\end{array}$} & \multicolumn{2}{|c|}{ Purpose of utilization } & \multirow{2}{*}{ Total } & \multirow{2}{*}{$\begin{array}{c}\text { Chi square } \\
\text { test }\end{array}$} & \multirow{2}{*}{$p$-value } \\
\hline & Agriculture & Non-agriculture & & & \\
\hline \multirow{2}{*}{$<2$} & 70 & 13 & 83 & \multirow{8}{*}{5.371} & \multirow{8}{*}{$\begin{array}{l}0.068 \\
\text { NS }\end{array}$} \\
\hline & $84.30 \%$ & $15.70 \%$ & $100.00 \%$ & & \\
\hline \multirow{2}{*}{$2-5$} & 695 & 163 & 858 & & \\
\hline & $81.00 \%$ & $19.00 \%$ & $100.00 \%$ & & \\
\hline \multirow{2}{*}{$>5$} & 169 & 57 & 226 & & \\
\hline & $74.80 \%$ & $25.20 \%$ & $100.00 \%$ & & \\
\hline \multirow{2}{*}{ Total } & 934 & 233 & 1167 & & \\
\hline & $80 \%$ & $20 \%$ & $100 \%$ & & \\
\hline
\end{tabular}


Table 9. Impact of type of family on the purpose of agricultural credit utilization

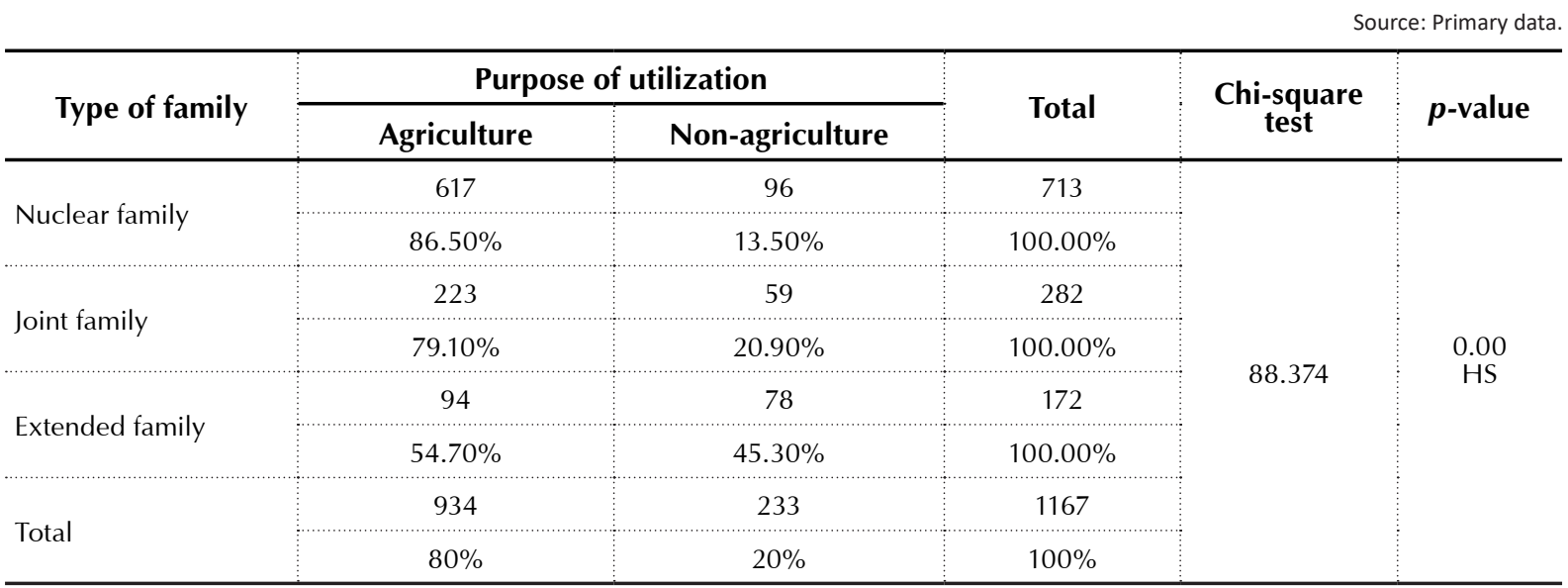

there is a highly significant impact of respondent's type of family on the purpose of agricultural credit utilization, as Chi-square test value is 88.374 and $p=0.000<0.01$. This is because 86.5 percent of the respondents with nuclear family have utilized agricultural credit for agricultural activities, which is significantly high compared to other types of family.

By analyzing the impact of various demographic factors of respondents on the purpose of utilization of agricultural credit funds by using Chi-square tests and p-values less than 0.05 , null hypotheses are rejected and it can be concluded that there is a significant impact of various demographic factors of respondents on the purpose of utilization of agricultural credit funds.

\subsection{Hypothesis 2}

H2.1: There is a significant impact of agriculture related factors of respondents on the purpose of utilization of agricultural credit funds.

Table 10. Impact of type of crops grown on the purpose of agricultural credit utilization

\begin{tabular}{|c|c|c|c|c|c|}
\hline \multirow{2}{*}{ Crops } & \multicolumn{2}{|c|}{ Purpose of utilization } & \multirow{2}{*}{ Total } & \multirow{2}{*}{ Chi-square test } & \multirow{2}{*}{$p$-value } \\
\hline & Agriculture & Non-agriculture & & & \\
\hline \multirow{2}{*}{ Paddy } & 74 & 44 & 118 & \multirow{20}{*}{52.545} & \multirow{20}{*}{$\begin{array}{c}0.00 \\
\mathrm{HS}\end{array}$} \\
\hline & $62.70 \%$ & $37.30 \%$ & $100.00 \%$ & & \\
\hline \multirow{2}{*}{ Coconut } & 37 & 5 & 42 & & \\
\hline & $88.10 \%$ & $11.90 \%$ & $100.00 \%$ & & \\
\hline \multirow{2}{*}{ Areca nut } & 338 & 100 & 438 & & \\
\hline & $77.20 \%$ & $22.80 \%$ & $100.00 \%$ & & \\
\hline \multirow{2}{*}{ Rubber } & 36 & 12 & 48 & & \\
\hline & $75.00 \%$ & $25.00 \%$ & $100.00 \%$ & & \\
\hline \multirow{2}{*}{ Other crops } & 7 & 0 & 7 & & \\
\hline & $100.00 \%$ & $0.00 \%$ & $100.00 \%$ & & \\
\hline \multirow{2}{*}{ All crops } & 25 & 1 & 26 & & \\
\hline & $96.20 \%$ & $3.80 \%$ & $100.00 \%$ & & \\
\hline \multirow{2}{*}{ Commercial crops } & 199 & 18 & 217 & & \\
\hline & $91.70 \%$ & $8.30 \%$ & $100.00 \%$ & & \\
\hline \multirow{2}{*}{ Traditional crops } & 81 & 24 & 105 & & \\
\hline & $77.10 \%$ & $22.90 \%$ & $100.00 \%$ & & \\
\hline \multirow{2}{*}{ Coco \& areca nut } & 137 & 29 & 166 & & \\
\hline & $82.50 \%$ & $17.50 \%$ & $100.00 \%$ & & \\
\hline \multirow{2}{*}{ Total } & 934 & 233 & 1167 & & \\
\hline & $80 \%$ & $20 \%$ & $100 \%$ & & \\
\hline
\end{tabular}


Table 11. Impact of the landholding size on the purpose of agricultural credit utilization

\begin{tabular}{|c|c|c|c|c|c|}
\hline \multirow{2}{*}{ Landholding size } & \multicolumn{2}{|c|}{ Purpose of utilization } & \multirow{2}{*}{ Total } & \multirow{2}{*}{$\begin{array}{c}\text { Chi-square } \\
\text { test }\end{array}$} & \multirow{2}{*}{$p$-value } \\
\hline & Agriculture & Non-agriculture & & & \\
\hline \multirow{2}{*}{ Less than 1 acres } & 41 & 31 & 72 & \multirow{12}{*}{48.77} & \multirow{12}{*}{0.00} \\
\hline & $56.90 \%$ & $43.10 \%$ & $100.00 \%$ & & \\
\hline \multirow{2}{*}{ Small (1-2) } & 292 & 61 & 353 & & \\
\hline & $82.70 \%$ & $17.30 \%$ & $100.00 \%$ & & \\
\hline \multirow{2}{*}{ Semi medium (2-4) } & 285 & 97 & 382 & & \\
\hline & $74.60 \%$ & $25.40 \%$ & $100.00 \%$ & & \\
\hline \multirow{2}{*}{ Medium (4-10) } & 173 & 31 & 204 & & \\
\hline & $84.80 \%$ & $15.20 \%$ & $100.00 \%$ & & \\
\hline \multirow{2}{*}{ Above 10} & 143 & 13 & 156 & & \\
\hline & $91.70 \%$ & $8.30 \%$ & $100.00 \%$ & & \\
\hline \multirow{2}{*}{ Total } & 934 & 233 & 1167 & & \\
\hline & $80 \%$ & $20 \%$ & $100 \%$ & & \\
\hline
\end{tabular}

H2.0: There is no significant impact of agriculture related factors of respondents on the purpose of utilization of agricultural credit funds.

To test the above hypothesis, the impact of various agriculture related factors of respondents on the purpose of utilization of agricultural credit funds are analyzed by using Chi-square tests.

It is seen from Table 10 that, in case of respondents who cultivated paddy, 37.3 percent have utilized agricultural credit funds for non-agricultural activities, whereas in case of commercial crops, only 8.3 percent of the respondents have utilized agricultural credit for non-agricultural activities. There is a significant impact of the type of crops cultivated by the respondents on the purpose of utilization of agricultural credit, as Chi-square test value is 52.545 and $p=0.000<0.01$.

It is found (see Table 11) that 43.1 percent of respondents with less than 1 acres of farm land, 25.4 percent of respondents with 2-4 acres of farm land (semi medium), 17.3 percent of respondents with 1-2 acres of farm land (small), 15.2 percent of respondents with 4-10 acres of farm land (medium) and 8.3 percent of respondents with above 10 acres of farm land (large) have utilized agricultural credit for non-agricultural activities. There is a highly significant impact on the purpose of utilization of agricultural credit, as Chi-square test value is 52.545 and $p=0.000<0.01$. It can be observed that the majority of the respondents with above 10 acres landholding size have paid the installments in time. Thus landholding size influenced the utilization of agricultural credit funds.

It is seen from Table 12 that 36.8 percent of the respondents who engaged less than 30 man days in agriculture per year, 20.6 percent of the respondents who engaged above 240 man days in agriculture per year, 2 percent of the respondents who engaged 211-240 man days in agriculture per year and none of the respondents who engaged 121150 man days in agriculture per year have utilized agricultural credit for non-agricultural activities. There is a highly significant impact on the purpose of utilization of agricultural credit, as Chi-square test value is 87.959 and $p=0.000<0.01$. Thus the number of man days spent by borrowers on agriculture has influenced the payment pattern of installments.

Table 13 shows that 28.7 percent of respondents with 2-4 years of experience in agriculture, 23.4 percent respondents with 5-7 years of experience in agriculture, 18.2 percent of respondents with more than 10 years of experience in agriculture and none of the respondents with less than two years of experience in agriculture have utilized agricultural credit for non-agricultural activities. There is a highly significant impact on the purpose of utilization of agricultural credit, as Chi-square test value is 238.474 and $p=0.000<0.01$. 
Table 12. Impact of number of days engaged in agriculture per year on the purpose of agricultural credit utilization

\begin{tabular}{|c|c|c|c|c|c|}
\hline \multirow{2}{*}{ No. of days } & \multicolumn{2}{|c|}{ Purpose of utilization } & \multirow{2}{*}{ Total } & \multirow{2}{*}{ Chi-square test } & \multirow{2}{*}{$p$-value } \\
\hline & Agriculture & Non-agriculture & & & \\
\hline \multirow{2}{*}{$<30$} & 12 & 7 & 19 & \multirow{20}{*}{87.959} & \multirow{20}{*}{$\begin{array}{c}0.00 \\
\mathrm{HS}\end{array}$} \\
\hline & $63.20 \%$ & $36.80 \%$ & $100.00 \%$ & & \\
\hline \multirow{2}{*}{$30-60$} & 77 & 12 & & & \\
\hline & $86.50 \%$ & $13.50 \%$ & $100.00 \%$ & & \\
\hline \multirow{2}{*}{$61-90$} & 92 & 34 & 126 & & \\
\hline & $73.00 \%$ & $27.00 \%$ & $100.00 \%$ & & \\
\hline \multirow{2}{*}{$91-120$} & 101 & 50 & 151 & & \\
\hline & $66.90 \%$ & $33.10 \%$ & $100.00 \%$ & & \\
\hline \multirow{2}{*}{$121-150$} & 86 & 0 & 86 & & \\
\hline & $100.00 \%$ & $0.00 \%$ & $100.00 \%$ & & \\
\hline \multirow{2}{*}{$151-180$} & 67 & 24 & 91 & & \\
\hline & $73.60 \%$ & $26.40 \%$ & $100.00 \%$ & & \\
\hline \multirow{2}{*}{$181-210$} & 42 & 22 & 64 & & \\
\hline & $65.60 \%$ & $34.40 \%$ & $100.00 \%$ & & \\
\hline \multirow{2}{*}{$211-240$} & 145 & 3 & 148 & & \\
\hline & $98.00 \%$ & $2.00 \%$ & $100.00 \%$ & & \\
\hline \multirow{2}{*}{$>240$} & 312 & 81 & 393 & & \\
\hline & $79.40 \%$ & $20.60 \%$ & $100.00 \%$ & & \\
\hline \multirow{2}{*}{ Total } & 934 & 233 & 1167 & & \\
\hline & $80 \%$ & $20 \%$ & $100 \%$ & & \\
\hline
\end{tabular}

It is found that 24 percent of respondents who have used machinery in agriculture and 13.5 percent of respondents who have not used machinery in agriculture have utilized agricultural credit for non-agricultural activities. There is a highly significant impact on the purpose of utilization of agricultural credit, as Chi-square test value is 34.693 and $p=0.000<0.01$.
By analyzing the impact of various agricultural credit factors of respondents on the purpose of utilization of agricultural credit funds by using Chi-square tests and p-values less than 0.05 , null hypotheses are rejected and it can be inferred that there is a significant impact of various agriculture related factors of respondents on the purpose of utilization of agricultural credit funds.

Table 13. Impact of number of years in agriculture on the purpose of agricultural credit utilization

\begin{tabular}{|c|c|c|c|c|c|}
\hline \multirow{2}{*}{ No. of years } & \multicolumn{2}{|c|}{ Purpose of utilization } & \multirow{2}{*}{ Total } & \multirow{2}{*}{ Chi-square test } & \multirow{2}{*}{$p$-value } \\
\hline & Agriculture & Non-agriculture & & & \\
\hline \multirow{2}{*}{$<2$} & 13 & 0 & 13 & \multirow{12}{*}{238.474} & \multirow{12}{*}{$\begin{array}{c}0.00 \\
\mathrm{HS}\end{array}$} \\
\hline & $100.00 \%$ & $0.00 \%$ & $100.00 \%$ & & \\
\hline \multirow{2}{*}{$2-4$} & 57 & 23 & 80 & & \\
\hline & $71.30 \%$ & $28.70 \%$ & $100.00 \%$ & & \\
\hline \multirow{2}{*}{$5-7$} & 95 & 29 & 124 & & \\
\hline & $76.60 \%$ & $23.40 \%$ & $100.00 \%$ & & \\
\hline \multirow{2}{*}{$8-10$} & 65 & 24 & 89 & & \\
\hline & $73.00 \%$ & $27.00 \%$ & $100.00 \%$ & & \\
\hline \multirow{2}{*}{$>10$} & 704 & 157 & 861 & & \\
\hline & $81.80 \%$ & $18.20 \%$ & $100.00 \%$ & & \\
\hline \multirow{2}{*}{ Total } & 934 & 233 & 1167 & & \\
\hline & $80 \%$ & $20 \%$ & $100 \%$ & & \\
\hline
\end{tabular}


Table 14. Impact of use of machinery on the purpose of agricultural credit utilization

\begin{tabular}{|c|c|c|c|c|c|}
\hline \multirow{2}{*}{$\begin{array}{c}\text { Use of } \\
\text { machinery }\end{array}$} & \multicolumn{2}{|c|}{ Purpose of utilization } & \multirow{2}{*}{ Total } & \multirow{2}{*}{ Chi-square test } & \multirow{2}{*}{$p$-value } \\
\hline & Agriculture & Non-agriculture & & & \\
\hline \multirow{2}{*}{ Yes } & 548 & 173 & 721 & \multirow{6}{*}{34.693} & \multirow{6}{*}{$\begin{array}{c}0.00 \\
\mathrm{HS}\end{array}$} \\
\hline & $76.00 \%$ & $24.00 \%$ & $100.00 \%$ & & \\
\hline \multirow{2}{*}{ No } & 386 & 60 & 446 & & \\
\hline & $86.50 \%$ & $13.50 \%$ & $100.00 \%$ & & \\
\hline \multirow{2}{*}{ Total } & 934 & 233 & 1167 & & \\
\hline & $80 \%$ & $20 \%$ & $100 \%$ & & \\
\hline
\end{tabular}

\subsection{Hypothesis 3}

H3.1: There is a significant impact of agricultural credit related factors of respondents on the purpose of utilization of agricultural credit funds.

H3.0: There is no significant impact of agricultural credit related factors of respondents on the purpose of utilization of agricultural credit funds.

To test the impact of various agricultural credit related factors of respondents on the purpose of utilization of agricultural credit funds, Chi-square tests are used.

It is found from Table 15 that 32.3 percent of respondents who have taken long-term agricultural credit have utilized agricultural credit funds for non-agricultural activities whereas only 10.7 percent of respondents who have taken short-term agricultural credit have utilized agricultural credit funds for non-agricultural activities. There is a highly significant impact of the respondents' term of agricultural credit on the purpose of agricultural credit utilization, as Chi-square test value is 51.996, $p=0.000<0.01$.

It is found from Table 16 that 37.8 percent of respondents who have taken agricultural credit with the half yearly frequency have utilized agricultural credit for non-agricultural activities, whereas only none of the respondents who have taken agricultural credit with the quarterly frequency have utilized agricultural credit for non-agricultural activities. There is a highly significant impact of the respondents' term of agricultural credit on the purpose of utilization of agricultural credit, as Chi-square test value is 51.996, $p=0.000<0.01$.

Talle 17 shows that 27.1 percent of respondents who are awared of schemes of agricultural credit and 13.5 percent of respondents who are not awared of the schemes have utilized agricultural credit for non-agricultural activities. There is a highly significant impact on the purpose of utilization of agricultural credit, as Chi-square test value is 20.279 and $p=0.000<0.01$.

Table 15. Impact of term of credit on the purpose of agricultural credit utilization

Source: Primary data.

\begin{tabular}{|c|c|c|c|c|c|}
\hline Term & Agriculture & Non-agriculture & Total & Chi-square test & $p$-value \\
\hline \multirow{2}{*}{ Short-term } & 33 & 276 & 309 & \multirow{8}{*}{51.996} & \multirow{8}{*}{$\begin{array}{c}0.00 \\
\mathrm{HS}\end{array}$} \\
\hline & $10.7 \%$ & $89.3 \%$ & $100.00 \%$ & & \\
\hline \multirow{2}{*}{ Medium-term } & 88 & 423 & 511 & & \\
\hline & $17.2 \%$ & $82.8 \%$ & $100.00 \%$ & & \\
\hline \multirow{2}{*}{ Long-term } & 112 & 235 & 347 & & \\
\hline & $32.3 \%$ & $67.7 \%$ & $100.00 \%$ & & \\
\hline \multirow{2}{*}{ Total } & 934 & 233 & 1167 & & \\
\hline & $80 \%$ & $20 \%$ & $100 \%$ & & \\
\hline
\end{tabular}


Table 16. Impact of credit frequency on the purpose of agricultural credit utilization

\begin{tabular}{|c|c|c|c|c|c|}
\hline \multirow{2}{*}{ Frequency } & \multicolumn{2}{|c|}{ Purpose of utilization } & \multirow{2}{*}{ Total } & \multirow{2}{*}{$\begin{array}{c}\text { Chi-square } \\
\text { test }\end{array}$} & \multirow{2}{*}{$p$-value } \\
\hline & Agriculture & Non-agriculture & & & \\
\hline \multirow{2}{*}{ Monthly } & 19 & 31 & 50 & \multirow{10}{*}{102.617} & \multirow{10}{*}{$\begin{array}{c}0.00 \\
\mathrm{HS}\end{array}$} \\
\hline & $38.00 \%$ & $62.00 \%$ & $100.00 \%$ & & \\
\hline \multirow{2}{*}{ Quarterly } & 62 & 0 & 62 & & \\
\hline & $100.00 \%$ & $0.00 \%$ & $100.00 \%$ & & \\
\hline \multirow{2}{*}{ Half yearly } & 79 & 48 & 127 & & \\
\hline & $62.20 \%$ & $37.80 \%$ & $100.00 \%$ & & \\
\hline \multirow{2}{*}{ Yearly } & 774 & 154 & 928 & & \\
\hline & $83.40 \%$ & $16.60 \%$ & $100.00 \%$ & & \\
\hline \multirow{2}{*}{ Total } & 934 & 233 & 1167 & & \\
\hline & $80 \%$ & $20 \%$ & $100 \%$ & & \\
\hline
\end{tabular}

Table 17. Impact of the awareness of schemes on the purpose of agricultural credit utilization

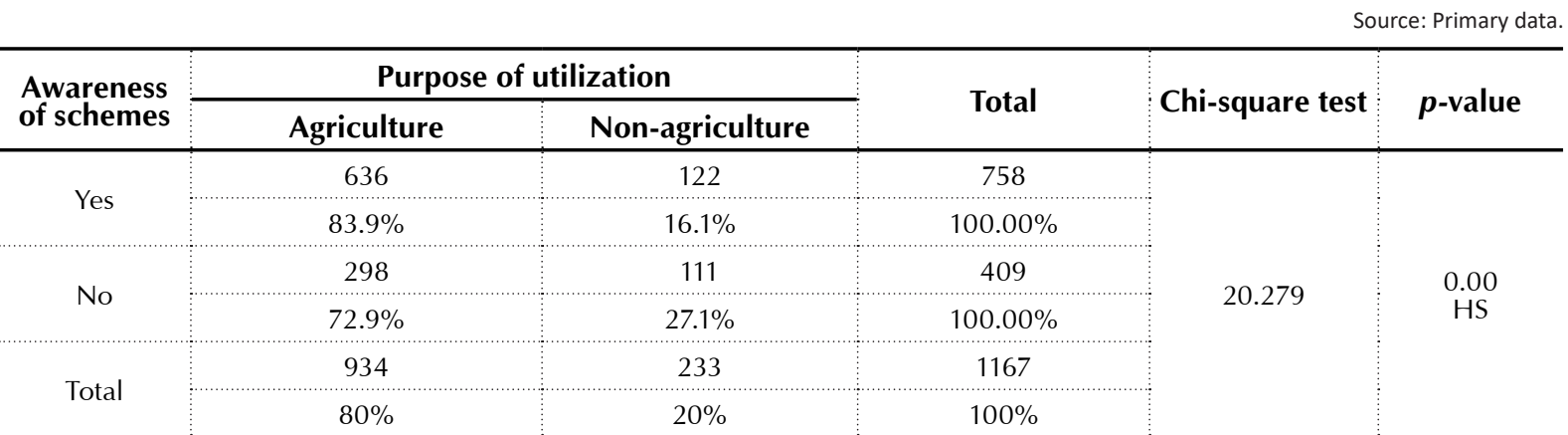

By analyzing the impact of various agricultural credit factors of respondents on the purpose of utilization of agricultural credit funds by using Chi-square tests and p-values less than 0.05 , null hypotheses are rejected and it can be concluded that there is a significant impact of various agricultural credit related factors of respondents on the purpose of utilization of agricultural credit funds. From the above hypothesis, it can be stated that personal, agriculture and credit related factors can influence the utilization pattern of agricultural credit funds by the borrowers. The utilization pattern in turn influences the repayment pattern of credit by the borrowers. The knowledge on this helps the bankers to understand the effectiveness of agricultural credit mechanism.

\section{CONCLUSION}

The banks in India consisting of public, private, cooperative and regional rural banks have made a remarkable progress in disbursement of agricultural credit. The success of agricultural credit system is determined by several factors and one of them is the purpose of utilization of borrowed funds. The study takes into account the borrowers of all types of banks and analyzes the factors influencing the utilization of agricultural credit. The study results show that demographic, agriculture and agriculture related factors influence the purpose of utilization of agricultural credit borrowed from banks by the farmers in Dakshina Kannada district. The policy makers can make note of the utilization pattern of agricultural credit and can give directions on the lending terms and conditions. There is a scope for further studies on the repayment of agricultural credit and the problems in repayment of agricultural credit by banks. 


\section{REFERENCES}

1. Alexpandi, M., \& Rameshkumar, S. (2014). Utilization and Repayment of Agricultural Credit the Case of Madhurai district, Tamil Nadu. Journal of Rural Development, 33(2), 147-159.

2. Ali, M. H., Chakrabarty, D., Choudhary, A., \& Banerjee, B. N. (2011). Magnitude of loan disbursed and utilization by the members of Self Help Group of Goragaccha village of Nadia Dist, West Bengal. Journal of Interacademicia, 15(1), 153-166.

3. Chahal, S. (2011). Supply and utilization pattern of agricultural credit: A study of selected credit institutions of Haryana. International Journal of Research in Computer Application and Management, 1(2), 105-111.

4. Das, A., Senapati, M., \& John, J. (2009). Impact of agricultural credit on cultural agriculture production: an Empirical analysis in India. Reserve Bank of India Occasional Papers, 30(2), 77-107.

5. Dasgupta, S., \& Dey, G. (2015). A Study on Utilisation of Credit by Marginal Farmers in Nadia District of West Bengal. Economic Affairs, 60(2), 181-186. https://doi.org/10.5958/09764666.2015.00026.1

6. Gulathi, A., \& Bathla, S. (2002). Institutional Credit to Indian Agriculture: Defaults and Policy Options (Occasional Papers No. 23). Mumbai: National Bank for Agriculture and Rural Development (NABARD). Retrieved from https://www.nabard.org/demo/auth/writereaddata/ File/OC\%2023.pdf
7. Kumar A., Mishra, A. K., Saroj, S., \& Joshi, K. P. (2017). Institutional versus Non institutional Credit to Agricultural Households in India Evidence on Impact from a National Farmers' Survey (Discussion Paper 01614). South Asia Office: IFPRI. Retrieved from http://www.ifpri.org/publication/ institutional-versus-noninstitutional-credit-agricultural-households-india-evidence

8. Kumar A., Singh, K., \& Kumar, P. (2007). Performance of Rural Credit and Factors Affecting the Choice of Credit Sources. Indian Journal of Agricultural Economics, 62(3), 297-312. Retrieved from https://ageconsearch.umn.edu/ record/204524/files/02-Anjani\%20 Kumar-Rural\%20Credit.pdf

9. Kumar A., Singh, K., \& Sinha, S. (2010). Institutional Credit to Agriculture Sector in India: Status, Performance and Determinants. Agricultural Economics Research Review, 23(2), 253-264. Retrieved from https://core.ac.uk/download/ pdf/6455749.pdf

10. Kumar, Santhosh (2013). Access, Use and Repayment of MicroCredit in Kerala - An Analysis. Journal of Rural Development, 32(3), 263-280. Retrieved from http://nirdprojms.in/index.php/ jrd/article/download/93320/69145

11. Lokesha, Hawaldar, I. T., \& Ishwara, P. (2017). An Evaluation of Pre- and Post-Sanction Process in Agricultural credit by Banks. International Journal of Economic Research, 14(14), 151-165. Retrieved from https://www.researchgate.net/
publication/321017416_An_ Evaluation_of_Pre-and_ Post_Sanction_Process_in_Agriculture_Credit_by_Banks

12. Lokesha. (2016). Agricultural credit by Banks in Dakshina Kannada District. An Analysis from Borrowers and Lenders Perspective (Ph.D. Thesis). Mangalore University.

13. Mishra, J. P., \& Subhay, R. (2003). Role of institutional credit for increasing income of the Marginal and small farmers in Sultanpur district of Uttar Pradesh. Cooperative Perspective, 38(2), 47-58.

14. Sapkal, S. B., Kumbhar, J. S., \& Shinde, H. R. (2010). Borrowing and utilization pattern of cooperative credit in Satara district of Maharashtra. Cooperative Sugar, 42(4), 45-49.

15. Seena, P. C. (2015). Management of Agricultural Credit and the Impact of Indian Banking Sector Reforms on Agriculture. International Review of Research in Emerging Markets and the Global Economy (IRREM). An Online International Research Journal, 1(3), 378-391. Retrieved from http://globalbizresearch. org/files/6003_irrem_seenap-147836.pdf

16. Selvaraj, N., \& Palajikumar, P. (2015). The Role of Commercial Banks in Providing Agricultural Credit (Factors Responsible for Overdue Position) - A Study with Reference to Tamil Nadu in India. International Journal of Accounting Research, 3, 116. 